\title{
Use of a computer for producing microbiological reports and for data storage and processing
}

\author{
J. L. FARRAR, T. D. BROGAN, T. MOULDING, R. TAYLOR, AND M. PAGE
}

From the Department of Clinical Bacteriology, University Hospital of Wales, Heath Park, Cardiff and the. Welsh Health Technical Services Organization Computer Centre, Velindre Hospital, Whitchurch, Cardiff

SYNOPSIS A simple 'fail-safe' system is described that produces microbiology reports on a computer ${ }^{\infty}$ teleprinter and stores results on the magnetic tapes and discs of a computer for instant retrievalio and epidemiological analysis. The system, which has been in operation for over a year, involves the ${ }^{\circ}$ use of a modified conventional NCR request form. The top portion, which is completed manually을 by the laboratory staff, is coded by writing numbers in hatched boxes. The data thus written on to $\vec{c}$ the bottom portion are transcribed by punch operators on to paper tape and this data input is verified by double punching. The reports are normally produced automatically by the computer $\overrightarrow{0}$ terminal teleprinter, but in case of mechanical failure the manually completed request forms can be returned to wards and outpatient departments. The system permits a wide choice of options for epidemiological analysis, and six programmes are described, one of which produces a digest of the overall percentage antibiotic sensitivities of organisms from various sites.

Microbiological laboratories attached to large hospitals have experienced during the last decade an ever increasing demand for routine investigations. The consequent work-load on such laboratories has given rise to many problems; those connected with organizing teams of technicians who are competent to cope with rising numbers of specimens are soluble if sufficient personnel, apparatus, and laboratory space can be found. However, problems generated by the recording, storage, and analysis of results were hitherto amenable to solution only if office space could be found to accommodate large numbers of bulky filing cabinets and if an adequate number of clerical workers could be employed; and such options are now not always available.

Computers have long been used for data storage and for retrieval and analysis of records. We describe a simple 'fail-safe' system not only for storage of microbiological results with facilities for instant retrieval and epidemiological analysis but also for producing microbiological reports on the computer teleprinter. The system has been in use for over a year in the University Hospital of Wales.

Received for publication 25 November 1974.

\section{Material and Methods}

\section{COMPUTER EQUIPMENT}

An International Computers Limited (ICL) 1904S computer of the following characteristics is sited at? the Welsh Health Technical Services Organization, $\dot{-}$ Computer Centre, Whitchurch, Cardiff and is linked to the University Hospital of Wales, which is 0 approximately two miles away, by GPO telephone lines. The computer has a core store of $128 \mathrm{~K}$ and 24 bit words and offers storage facilities on both $>$ magnetic tape and disc. The computer is controlled $\stackrel{0}{\text {. }}$. by an operating system 'George III' which is capable of carrying out many operations simultaneously. It is therefore possible to input work from the ICL $N$ 7020 terminal while still processing other programs $\underset{\omega}{N}$ within the computer centre. The ICL 7020 terminal, housed on site at the University Hospital of Wales, 0 has a paper tape reader/punch and a line printer $\overparen{D}$ capable of printing 150 lines per minute. The suite $\stackrel{\mathcal{O}}{+}$ of programs is written mainly in Cabol.

INPUT OF DATA

A two-part National Cash Register (NCR) form $\frac{\Omega}{\stackrel{\Phi}{Q}}$ is used (BA1; fig 1a, b). The top portion is completed by the clinician in a manner similar to $\mathrm{a} O$ request on a conventional form, and the bottom 


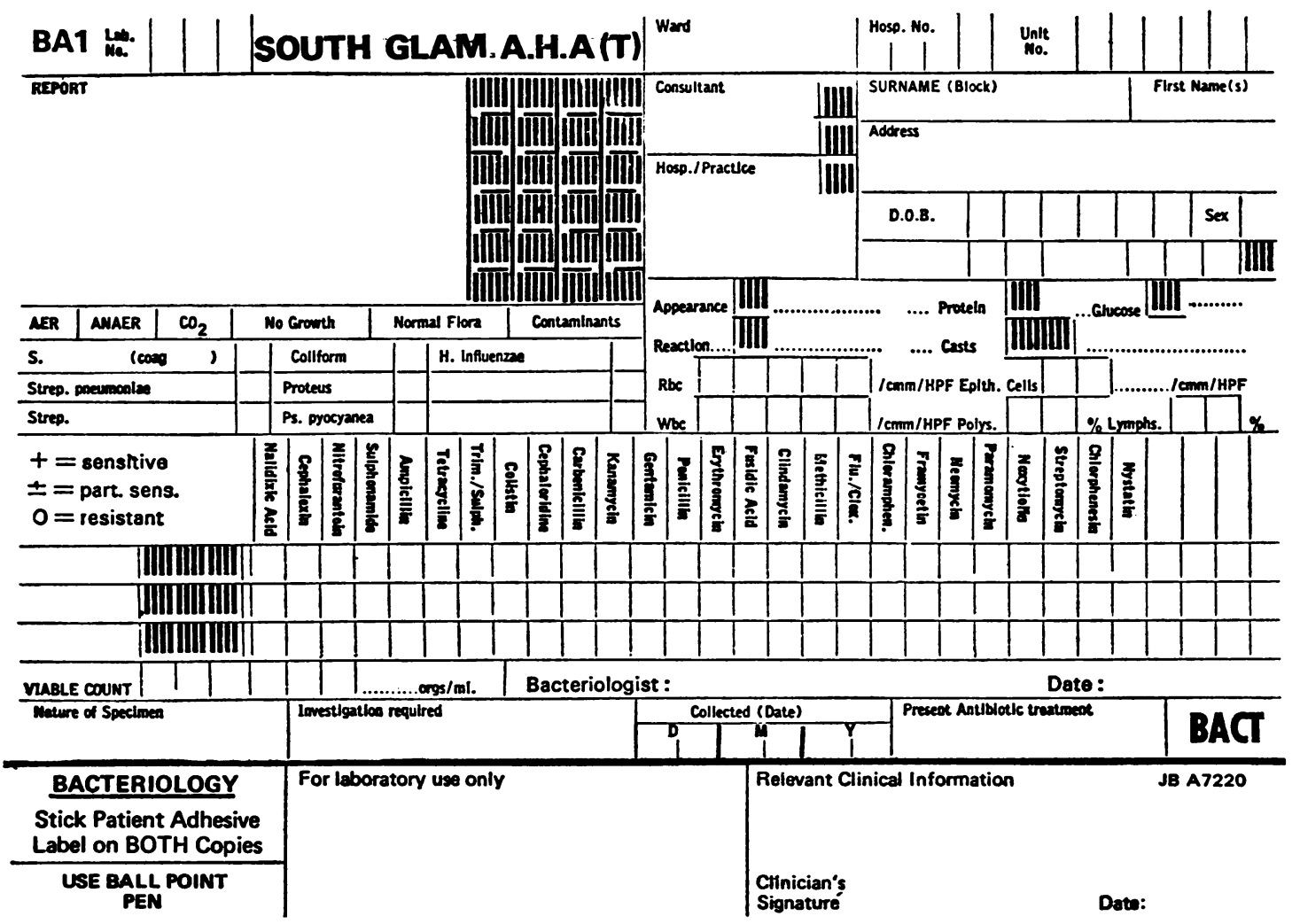

Fig 1 (a) Top portion of NCR computer form BAl which is completed by the clinician when sending a specimen to the bacteriology laboratory. This form could be used for manual reporting by the laboratory if computer failure occurs.

The laboratory staff code the results of the investigations by writing the code numbers in the hatched boxes. Cell counts on urine and CSF are written numerically in the appropriate boxes and antibiotic sensitivities are recorded as + or 0 (sensitive or resistant) against the antibiotic tested.

portion is used by the computer terminal operators for transcribing information on to punched paper tape. The form was designed for use by all hospitals in the South Glamorgan Area Health Authority and thus can be used for manual reporting in those hospitals that do not yet possess a computer terminal and by the University Hospital of Wales should a computer breakdown occur. Information, such as results of streptococcal grouping, 'phage typing, etc., that is additional to the data on the initial report is put into the computer by means of form BA2 (fig 1c) which is also used for coding the results of microbiological assays and of various serological tests.

\section{CODING FORM BA 1}

Patient identification labels, produced automatically in the hospital, can be attached to the top right-hand corner of the form by the person requesting the test. The details include hospital number, patient number, patient's name and address, date of birth, and sex. Other details concerning patient care, such as ward, name of consultant or general practitioner, nature of specimen, etc., are coded by the laboratory staff concerned with specimen reception.

Results of microscopy are coded by the technician examining the specimen with simple pre-determined numerical codes which are written in the appropriate hatched boxes on the top left-hand side of the top portion of the request form; this permits the additional option of manually writing the results so that the top portion of the form can be returned to the wards directly. Results of cell counts on cerebrospinal fluid or urine are recorded numerically in the open boxes on the top portion; these results are punched by the data preparation staff and can also be used for direct reporting on the specimen should this be necessary.

Organisms yielded by culture are coded digitally by numbers up to 999 (table I) and the codes of 


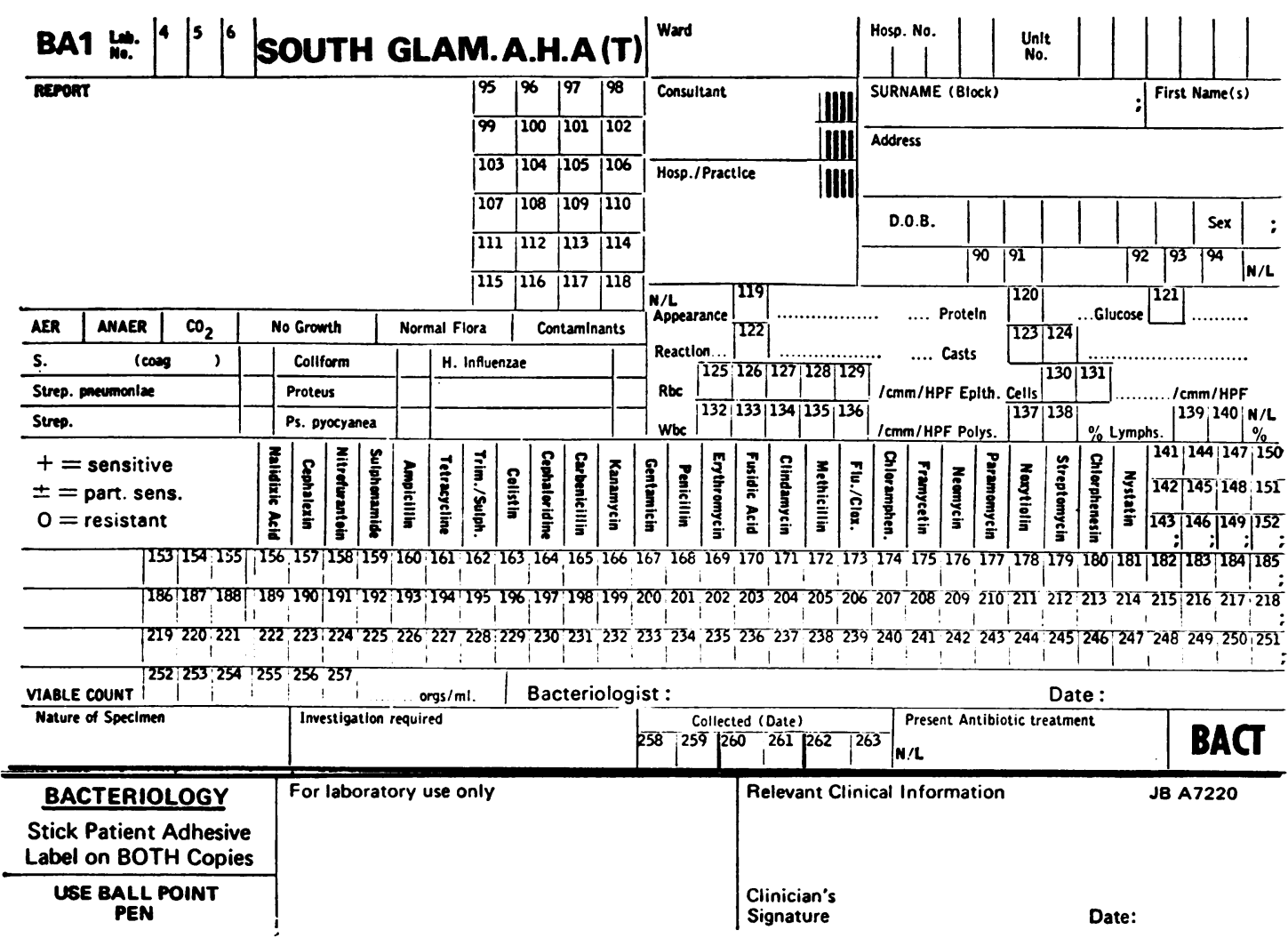

Fig 1 (b) Bottom portion of computer form BAI. This portion of the form is used by the computer terminal punch operator. The results coded on the top portion are transferred by the pen to this portion, and the information is transcribed by the terminal operator on to paper tape. This coded information is then put into the computer.

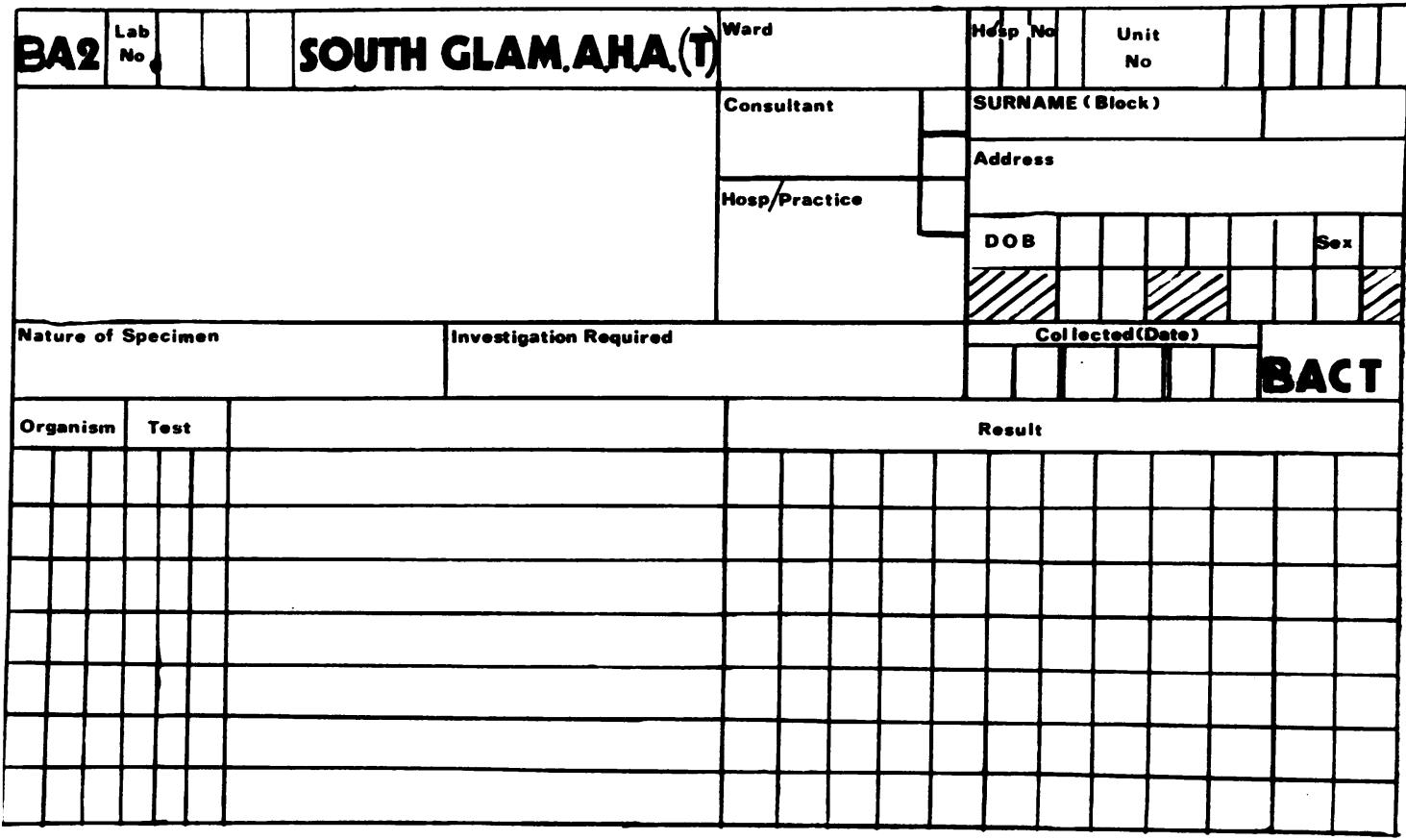

Fig 1 (c) Form BA2. This form is used by the laboratory for coding results additional to those written on form BA1. It thus enables the laboratory to put into the computer the results of serology tests, 'phage typing of staphylococci, streptococcal typing, etc. The results are stored in the computer against the patient's name and are reproduced as a report (fig 2) by the on-line printer of the terminal. 


\begin{tabular}{lll}
\hline Code & Result of Culture & $\begin{array}{l}\text { Abbreviation written by } \\
\text { On-line Terminal Printer }\end{array}$ \\
\hline 001 & No growth & NO GROWTH \\
002 & Normal flora & NORMAL FLORA \\
003 & Contaminants & CONTAMINANTS \\
004 & Proteus species & PROTEUS SP \\
005 & Klebsiella species & KLEBSIELLA SP \\
006 & Escherichia coli & E COLI \\
007 & Streptococcus faecalis & ST FAECALIS \\
008 & Haemophilus influenzae & H INFLUENZAE \\
009 & Streptococcus pneumoniae & ST PNEUMONIAE \\
010 & Staphylococcus albus & STAPH ALBUS \\
011 & Coliform & COLIFORM \\
012 & Enteropathogenic E. coli & EPE COLI \\
013 & Pseudomonas aeruginosa & PS PYOCYANEA \\
014 & Staphylococcus aureus & STAPH AUREUS \\
015 & B Haemolytic streptococcus & \\
& (presumed group A) & BHS (presumed A) \\
016 & Candida albicans & CAND ALBICANS \\
017 & Clostridium welchii & CL WELCHII \\
018 & Salmonella species & SALMONELLA sp \\
019 & Shigella sonnei & SHIG SONNEI \\
020 & Shigella flexneri & SHIG FLEXNERI \\
\hline
\end{tabular}

Table I List of frequently used codes that are employed to transcribe results of bacteriological culture to paper tape.

These numbers are written in the hatched boxes to the left of the antibiotic sensitivity boxes on the top portion of form BA1 (fig 1a) The way in which they appear on the computer form (fig 2) is given in the third column of the list. those organisms commonly isolated are grouped to facilitate learning. The code is recorded by writing the number in the hatched boxes on the top portion of form BA1 (fig 1a), and the name of the organism is ringed or written in full. Sensitivity tests are recorded + or 0 (sensitive or resistant) against the antibiotic tested, and this information is also transcribed by the punch operators on to punched tape.

The bottom portions of the form (fig 1b), after completion of specimen examination, are taken to the computer terminal in batches during the morning; requests for past results, statistical information, addition or amendments to codes, etc. are also put into the terminal during the morning run. Data are punched on Creede Envoy machines to paper tape; they are then checked by a second punch tape operator and the punch machine locks automatically if the second transcription does not agree with the first. Data input is thus verified by double punching before the information on the paper tape is transmitted to the computer.

\section{Results}

During every working day the computer terminal

HOSP

CRN

WARD

DOB

SEX

SPEC
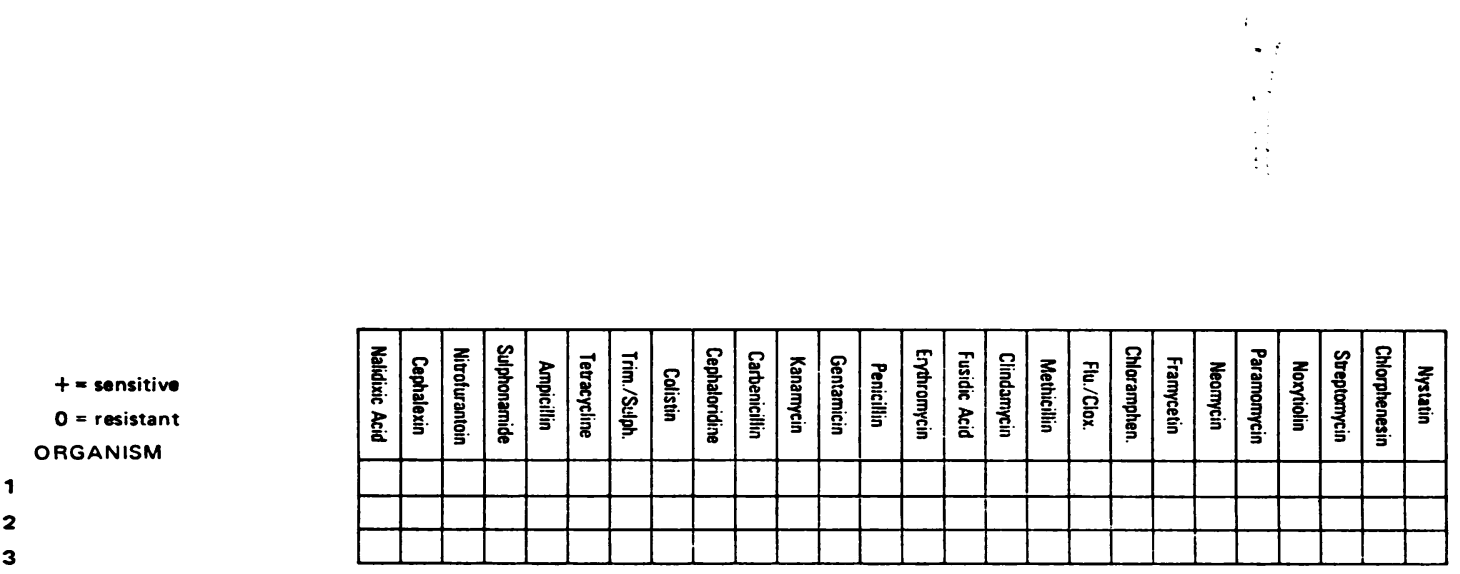

VIABLE COUNT

$\operatorname{orgs} / \mathrm{ml}$

DATE COLLECTED

Fig 2 (a) Pre-printed form on which the on-line terminal printer writes the report after punching and validation of data input. 


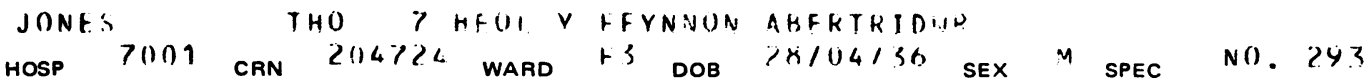

\begin{tabular}{|c|c|c|c|c|c|c|c|c|c|c|c|c|c|c|c|c|c|c|c|c|c|c|c|c|c|c|}
\hline $\begin{array}{c}\text { PROTEIN } \\
++\end{array}$ & $\begin{array}{c}G L \| C O \\
N] 1\end{array}$ & & & & $\begin{array}{l}A C \\
A C\end{array}$ & $\begin{array}{l}110 \\
10\end{array}$ & & & & & C A & $\$ T$ & $\mathrm{~s} /$ & HD & & & & RE & $\begin{array}{r}1 \\
1\end{array}$ & $\begin{array}{l}\text { HO } \\
\text { 0) }\end{array}$ & & FC & & B? & $\begin{array}{r}/ H \\
5\end{array}$ & \\
\hline \multirow{4}{*}{$\begin{array}{l}+=\text { sensitive } \\
0=\text { resistant } \\
\text { ORGANISM } \\
\text { F. COII I }\end{array}$} & 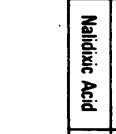 & 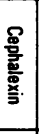 & 를 & 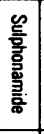 & 蛋 & 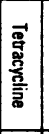 & 疍 & 올. & 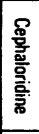 & 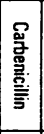 & 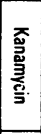 & : & 兽 & 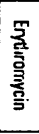 & 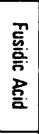 & 을 & 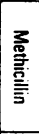 & 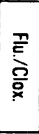 & 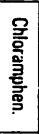 & 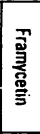 & 罾 & 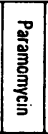 & 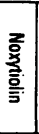 & 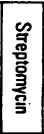 & 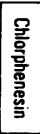 & 胥 \\
\hline & + & + & + & i) & (1) & ii) & + & + & & & & & & & & & & & & & & & & & & \\
\hline & & & & & & & & & & & & & & & & & & & & & & & & & & \\
\hline & & & & & & & & & & & & & & & & & & & & & & & & & & \\
\hline
\end{tabular}

VIABLE COUNT >101)IUUR Orgs/mI BACTERIOLOGY DEPARTMENT

DATE COLLECTED $27 / 11 / 74 \quad M S I I$

Fig 2 (b) Example of a computer-printed report on a mid-stream specimen of urine. The patient's name and address are printed in an agreed shortened form together with his hospital registration number $(C R N)$ and date of birth (DOB); other abbreviations have the following meanings:

HPF high powered field of microscope

$R B C / W B C$ red blood cells/white blood cells

EC epithelial cells

These reports conform to the locally agreed size and format for inclusion in patients' notes of hospitals of the South Glamorgan $A H A(T)$.

first prints a list of errors before it produces the results of the morning data input. This error list consists of unacceptable codes and rejecetd data that have been transmitted to the computer as a result of mistakes by laboratory personnel. Errors are corrected before the terminal prints the laboratory reports (fig $2 \mathrm{a}, \mathrm{b}$ ) which are produced in ward order to facilitate rapid sorting. In addition to the ward reports, the terminal produces a summary in alphabetical order of all results reported during the last 14 days. This day book enables results of investigations carried out during the last 14 days to be found instantly; results of reports older than 14 days are obtained from the computer by a request form and these are printed in the same way as a normal report.

With the present system, there is a wide choice for retrieval of epidemiological data and, to date, six programs are in operation. Monthly and quarterly digests are produced of the number of isolations of 10 common pathogens in each of the wards together with a monthly and quarterly report of the frequency with which the predominant type of $a$ particular species occurs (table II). In addition to this a monthly and a quarterly digest are produced of the overall percentage antibiotic sensitivity of organisms from various sites (table III).

\begin{tabular}{llll}
\hline Ward C1 & & & \\
\hline Organism & Test Name & Test Result & Repeat Types \\
\hline Ps pyocyanea & Pyo type & 1 & 5 \\
Staph aureus & Phage type & 52 52A 79 80 84 & 1 \\
& Phage type & 52 52A 80 42E 83 & 1 \\
& Phage type & 52W X 100 RTD & 1 \\
& Phage type & 71 RTD & 1 \\
& Phage type & 85 RTD & 2 \\
BHS (presumed & Phage type & NT & 5 \\
A) & Strep grp & Lancefield A & 6 \\
& Strep grp & Lancefield G & 1 \\
& Strep grp & Not Groupable & 1 \\
\hline
\end{tabular}

Table II Example of a quarterly report, printed by the computer terminal, on the type predominance of varions organisms isolated from a dermatology ward of the University Hospital of Wales 
SITE: Mid-stream urine

\begin{tabular}{|c|c|c|c|c|c|c|c|c|c|c|c|c|}
\hline Organism & $\begin{array}{l}\text { Overall No. of } \\
\text { Isolates tested }\end{array}$ & & $\begin{array}{l}\text { Nala- } \\
\text { dixic } \\
\text { Acid }\end{array}$ & $\begin{array}{l}\text { Cepha- } \\
\text { lexin }\end{array}$ & $\begin{array}{l}\text { Nitro } \\
\text { furan- } \\
\text { toin }\end{array}$ & $\begin{array}{l}\text { Sulphon- } \\
\text { amide }\end{array}$ & $\begin{array}{l}\text {-Ampi- } \\
\text { cillin }\end{array}$ & $\begin{array}{l}\text { Tetra- } \\
\text { cycline }\end{array}$ & $\begin{array}{l}\text { Cotri- } \\
\text { moxazole }\end{array}$ & $e^{\text {Colistin }}$ & $\begin{array}{l}\text { Carbeni- } \\
\text { cillin }\end{array}$ & $\begin{array}{l}\text { i- Genta- } \\
\text { micin }\end{array}$ \\
\hline Proteus species & 86 & $\begin{array}{l}\text { Sensitive } \\
\text { Non-sensitive } \\
\% \text { Sensitivity }\end{array}$ & $\begin{array}{r}83 \\
2 \\
98\end{array}$ & $\begin{array}{l}73 \\
13 \\
85\end{array}$ & $\begin{array}{r}3 \\
83 \\
3\end{array}$ & $\begin{array}{l}75 \\
10 \\
88\end{array}$ & $\begin{array}{r}80 \\
6 \\
93\end{array}$ & $\begin{array}{r}3 \\
83 \\
3\end{array}$ & $\begin{array}{r}85 \\
1 \\
99\end{array}$ & $\begin{array}{r}1 \\
84 \\
1\end{array}$ & $\begin{array}{l}0 \\
0 \\
0\end{array}$ & $\begin{array}{l}0 \\
0 \\
0\end{array}$ \\
\hline Streptococcus faeralis & 47 & $\begin{array}{l}\text { Sensitive } \\
\text { Non-sensitive } \\
\% \text { Sensitivity }\end{array}$ & $\begin{array}{r}2 \\
45 \\
4\end{array}$ & $\begin{array}{l}17 \\
30 \\
36\end{array}$ & $\begin{array}{r}47 \\
0 \\
100\end{array}$ & $\begin{array}{l}12 \\
35 \\
26\end{array}$ & $\begin{array}{r}45 \\
2 \\
96\end{array}$ & $\begin{array}{l}17 \\
30 \\
36\end{array}$ & $\begin{array}{r}43 \\
4 \\
91\end{array}$ & $\begin{array}{r}2 \\
45 \\
4\end{array}$ & $\begin{array}{l}\mathbf{0} \\
\mathbf{0} \\
\mathbf{0}\end{array}$ & $\begin{array}{l}0 \\
0 \\
0\end{array}$ \\
\hline Staphylococcus albus & 55 & $\begin{array}{l}\text { Sensitive } \\
\text { Non-sensitive } \\
\% \text { Sensitivity }\end{array}$ & $\begin{array}{r}6 \\
49 \\
11\end{array}$ & $\begin{array}{r}55 \\
0 \\
100\end{array}$ & $\begin{array}{r}55 \\
0 \\
100\end{array}$ & $\begin{array}{r}50 \\
5 \\
91\end{array}$ & $\begin{array}{l}26 \\
17 \\
60\end{array}$ & $\begin{array}{l}29 \\
26 \\
53\end{array}$ & $\begin{array}{l}44 \\
11 \\
80\end{array}$ & $\begin{array}{r}5 \\
50 \\
9\end{array}$ & $\begin{array}{l}0 \\
0 \\
0\end{array}$ & $\begin{array}{l}\mathbf{0} \\
\mathbf{0} \\
\mathbf{0}\end{array}$ \\
\hline Coliform species & 479 & $\begin{array}{l}\text { Sensitive } \\
\text { Non-sensitive } \\
\% \text { Sensitivity }\end{array}$ & $\begin{array}{r}457 \\
21 \\
96\end{array}$ & $\begin{array}{r}389 \\
89 \\
81\end{array}$ & $\begin{array}{r}433 \\
45 \\
91\end{array}$ & $\begin{array}{r}355 \\
123 \\
74\end{array}$ & $\begin{array}{r}307 \\
172 \\
64\end{array}$ & $\begin{array}{r}340 \\
139 \\
71\end{array}$ & $\begin{array}{r}458 \\
21 \\
96\end{array}$ & $\begin{array}{r}453 \\
21 \\
96\end{array}$ & $\begin{array}{r}9 \\
6 \\
60\end{array}$ & $\begin{array}{r}13 \\
2 \\
87\end{array}$ \\
\hline \multicolumn{2}{|c|}{ Pseudomonas aeruginosa 20} & $\begin{array}{l}\text { Sensitive } \\
\text { Non-sensitive } \\
\% \text { Sensitivity }\end{array}$ & $\begin{array}{r}0 \\
20 \\
0\end{array}$ & $\begin{array}{r}0 \\
20 \\
0\end{array}$ & $\begin{array}{r}0 \\
20 \\
0\end{array}$ & $\begin{array}{r}0 \\
20 \\
0\end{array}$ & $\begin{array}{r}0 \\
20 \\
0\end{array}$ & $\begin{array}{r}3 \\
17 \\
15\end{array}$ & $\begin{array}{r}0 \\
20 \\
0\end{array}$ & $\begin{array}{r}20 \\
0 \\
100\end{array}$ & $\begin{array}{r}16 \\
4 \\
80\end{array}$ & $\begin{array}{r}20 \\
0 \\
100\end{array}$ \\
\hline
\end{tabular}

Table III Example of a quarterly antibiotic sensitivity report printed by the computer terminal, on the likely proportion of antibiotic-sensitive strains in five groups of organisms commonly isolated in significant numbers from urine specimens

The numbers in the lines of the table headed 'sensitive' and 'non-sensitive' indicate the numbers of isolates subjected to direct disc sensitivity tests. '\% Sensitivity' indicates the likely proportion of sensitive strains of the organism or groups of organisms to the various antimicrobial drugs tested.

\section{Discussion}

The system for computerized reporting and data processing of clinical microbiology results that we have described makes use of a conventional request form, thus permitting instant reversion to manual reporting should mechanical failure occur within the computer system. Furthermore, other hospitals in a large area health authority use the same form and will be able to adopt the system as and when computer faciltities become available. A simple method of coding has been employed that is easy to learn and allows further inclusion of an almost limitless number of specimen types, organisms, investigations, etc. that future medical practice may yet demand. The double punching system enables automatic verification of computer data input, thus virtually eliminating errors from this source. This obviates the necessity for using manually punched cards as described in the Report on Data Processing in Clinical Pathology (1968); coding errors are therefore mostly confined to mistakes in coding that can be made by technicians at the bench and these usually become apparent to the consultant who is responsible for reporting. Instant retrieval of current results is made possible by a retrospective 14-day narrative 'day book' which also enables laboratory staff to assess present results on any particular patient against results yielded by recent microbiological investigations.

Information is stored centrally at the Welsh Health Technical Services Organization Computer Centre for an indefinite period on magnetic tape or on discs, thus dispensing with the need for bulky files from which it is rarely possible to retrieve epidemiological information. Programs can be written for the system we have described that will yield epidemiological data from the stored information. To date, we have confined programs to assessment of the incidence of pathogen isolation in our wards and to determining the average antibiotic sensitivity of recently isolated pathogenic bacteria. This has enabled us to counsel clinicians more effectively than before on the likely efficacy of an antimicrobial agent before definitive sensitivity tests are available. We are currently planning to assess the incidence of postoperative sepsis by computer program since we are now convinced that this most important epidemiological information can be produced as accurately as, and more efficiently than, by the manual methods that we have used hitherto.

Computerization of results as an exercise separate to that of using the terminal for reporting has been criticized by Whitby (1969), who described a system that uses several cards relating to various groups of specimens. Andrews and Vickers(1974) have devised a system of computer-assisted microbiology reporting that makes use of a separate marked-sense work sheet. Our system uses one single filing card (BA1) that is the bottom portion of a normal NCR request form and thus does away with the necessity for cards relating to groups of specimens or, in fact, for punching or processing separate computer cards. Additional information, such as 'phage types of staphylococci, pyocine typing of Pseudomonas 
aeruginosa, etc., can be reported to the clinician and stored against the patient's name by the simple expedient of completion of form BA2 by the laboratory staff. We thus consider that the system we have devised has considerable versatility and could be expanded to report and store an infinite variety of microbiological investigations. In addition, the system is 'fail-safe' should mechanical breakdown occur.

We should like to acknowledge our many colleagues in the clinical bacteriology laboratories of the University Hospital of Wales and in the Welsh
Health Technical Services Organization without whose help the production of this system would not have been possible.

\section{References}

Andrews, H. J. and Vickers, M. (1974). An assessment of one year of computer-assisted microbiology reporting at Charing Cross Hospital. J. clin. Path., 27, 185-191.

Report on Data Processing in Clinical Pathology (1968). J. clin. Path., 21, 231-301.

Whitby, J. L. (1969). In Automation and Data Processing in Pathology, edited by T. P. Whitehead. J. clin Path., Suppl. 3, p. 93. 